\title{
An analysis of EGR impact on combustion process in the SI test engine
}

\author{
The results of modelling of thermal cycle of spark ignition internal combustion engine with exhaust gas recircula- \\ tion are presented. Results of the impact of EGR on the ignition delay and the combustion duration are presented. The \\ optimization of thermal cycle was carried out in terms of ignition advance angle in order to obtain the possible highest \\ value of efficiency and the least NO emission. The results indicated a significant impact of EGR on the ignition delay \\ and combustion duration.
}

Key words: ignition delay, combustion duration, modelling, exhaust gas recirculation

\section{Analiza wplywu EGR na proces spalania w badawczym silniku ZI}

\begin{abstract}
W pracy przedstawiono wyniki modelowania obiegu cieplnego tłokowego silnika spalinowego z recyrkulacja spalin. Przedstawiono wyniki wptywu EGR na zwłokę zapłonu oraz na dtugość spalania. Przeprowadzono optymalizację obiegu silnika pod względem kąta wyprzedzenia zapłonu w celu osiagnięcia największej wartości sprawności obiegu przy niskiej emisji NO. Wyniki wykazały znaczny wplyw EGR na opóźnienie zapłonu i na dhugość spalania.

Słowa kluczowe: opóźnienie zapłonu, długość spalania, modelowanie, recyrkulacja spalin
\end{abstract}

\section{Introduction}

Ignition delay is the most important parameter of ignition and combustion of engines which will directly impact on the performance, emissions, combustion noise and other parameters. Number of researchers have been studied the ignition delay on constant-volume bomb, steady-flow reactor and internal combustion engine, respectively. The results showed that the ignition delay depends on the mixture of parameters, the temperature, pressure and the air fuel ratio [7]. Zou [18] and coworkers in their work has conducted an investigation on the ignition delay of a dual fuel engine operating with methanol ignited by pilot diesel on directinjection diesel engine. They found that the ignition delay increases with the increase in methanol mass fraction. With the increase in engine speed, the ignition delay of the dual fuel engine by time scale decreases clearly under all engine operating conditions [18]. Li and all [9] in their work has experimentally investigated the effects of injection and ignition timings on performance and emissions from a highcompression direct-injection stratified charge spark-ignition methanol engine. Methanol injection timing and ignition timing have a significant effect on engine performance, combustion, and exhaust emissions. At an engine speed of $1600 \mathrm{rpm}$, full load, after optimization of injection and ignition timings, engine can obtain shorter ignition delay, lower cycle-by-cycle variation, the maximum in-cylinder pressure, the maximum heat release rate, and higher thermal efficiency compared to the case of non-optimized injection and ignition timings [9]. For the smallest values of ignition delay, they had received the highest value of indicated efficiency of engine. The smallest value to ignition delay was $16 \mathrm{deg}$, with efficiency at nearly $52 \%$. Under these conditions, there was also the smallest cycle-to-cycle variations. Yamin and coworkers [17] has investigated an effect of combustion

\section{Wstęp}

Zwłoka zapłonu jest bardzo ważnym parametrem inicjowania zapłonu oraz procesu spalania $\mathrm{w}$ silniku. Wpływa ona bezpośrednio na parametry silnika, emisję spalin, hałas spalania oraz inne parametry. Wielokrotnie badano zjawisko opóźnienia zapłonu w komorach o stałej objętości, w reaktorach o ustalonym przepływie lub w silniku spalinowym. Uzyskane rezultaty pokazały, że zwłoka zapłonu zależy od parametrów mieszanki, temperatury, ciśnienia oraz od współczynnika nadmiaru powietrza [7]. Zou i inni [18] prowadzili badania określające zwłokę zapłonu w silniku dwupaliwowym pracującym na metanolu, o zapłonie inicjowanym dawką wtryskiwanego oleju napędowego. Stwierdzili oni, że zwłoka zapłonu wzrasta ze wzrostem udziału masowego metanolu. Wraz ze wzrostem prędkości obrotowej silnika, w silniku dwupaliwowym, zwłoka zapłonu maleje we wszystkich warunkach pracy silnika [18]. Li i inni [9] badali eksperymentalnie wpływ kąta wtrysku paliwa i zapłonu na parametry oraz emisję spalin silnika ZI o wysokim stopniu sprężania, zasilanego metanolem. Kąt wtrysku metanolu oraz kąt zapłonu miały znaczący wpływ na parametry silnika, spalanie i emisję spalin. Przy prędkości obrotowej $1600 \mathrm{obr} / \mathrm{min}$, pełnym obciążeniu, po optymalizacji kątów wtrysku i zapłonu uzyskano najmniejszy czas zwłoki zapłonu, najmniejszą niepowtarzalność obiegu w kolejnych cyklach, maksymalne ciśnienie, największą szybkość wydzielania ciepła i największą sprawność w porównaniu do osiągów przed optymalizacją [9]. Dla najmniejszych wartości zwłoki zapłonu uzyskali oni największą wartość sprawności silnika. Najmniejsza wartość zwłoki zapłonu wynosiła $16^{\circ}$ OWK, przy sprawności około $53 \%$. W tych warunkach uzyskano także najmniejszą niepowtarzalność cykli pracy silnika. Yamin i inni [17] badali wpływ długości spalania 
duration on the performance and emission characteristics of a spark ignition engine. The main conclusion of their study was that the combustion duration has a significant effect on both performance and emission characteristics of the engine and has to be carefully designed to achieve the best engine performance characteristics. They also found that operating at lean or rich mixtures tends to increase the combustion duration. This effect was more predominant at higher speeds. This was because of the lesser energy contained in leaner mixtures which increases the ignition delay and slows the flame propagation. They also reported that the combustion duration has minimum at equivalence ratios nearly equal to 1.0 for all engine speeds [17]. An increase in the combustion duration caused the peak temperature and the brake mean effective pressure to decreased. This was because of the increased heat losses. On the basis of the results [17], they reported that for better performance in terms of power and economy, the combustion duration has to be between 4-6 $\mathrm{ms}$ which means that the engine should run on a mixture slightly leaner than stoichiometric $(\lambda=1.0-1.1)$. Bayraktar and Durgun [4] has presented the development of an empirical correlation for combustion duration for SI engine. In that correlation, the effects of engine operating parameters on combustion duration were taken into account. Combustion duration was taken as the crank angle interval from the time of spark discharge to the instant at which the charge is fully burned. Based on modelling results, it was found that the increase in compression ratio from 7 to 8.5 resulted in decreasing of combustion duration. Further increase the rate of compression did not cause decreasing of combustion duration (engine parameters: $\mathrm{n}=1000 \mathrm{rpm}, \mathrm{ST}=-30 \mathrm{CABTDC}$, $\lambda=1.0$ ). It was also found that a very significant impact on the duration of combustion has the ignition angle.

Based on an analysis of selected research work can be stated that the duration of the combustion in the engine is essential to obtained parameters of the engine and exhaust toxicity. The paper presented results of modelling the impact of EGR on the ignition delay and the combustion duration of spark ignition internal combustion engine.

\section{Modelling results}

Modelling of the thermal cycle of the test SI engine using the FIRE software [3] was conducted. As the research object was taken internal combustion spark ignition, naturally aspirated test engine S320ER, operated at constant rotational speed equal to $1000 \mathrm{rpm}$. The researches was conducted for a wide range of excess air ratio and EGR share, accepted by engine. During the model tests the cold EGR was used. During the experimental researches engine was characterized by a high tendency to knock. Optimizing the engine thermal cycle, the knock process was considered [11, 14-16].

As a fuel $\mathrm{C}_{8} \mathrm{H}_{17}$ hydrocarbon (gasoline) was taken. For modelling the combustion process used Extended Coherent Flame Model (ECFM) [3]. Turbulence was modeled using k-zeta-f model. Homogeneous mixture was delivered to the cylinder. The percentage of exhaust gases recycled back to the engine intake (\% EGR) was calculated as a percentage na charakterystyczne parametry termodynamiczne i emisję silnika o zapłonie iskrowym. Głównym wnioskiem było stwierdzenie, że długość spalania ma istotny wpływ zarówno na osiągi, jak i emisję silnika i parametr ten powinien być starannie określony w celu uzyskania optymalnych parametrów pracy silnika. Stwierdzili także, że praca silnika na mieszance ubogiej lub bogatej powoduje wydłużenie czasu spalania. Efekt ten jeszcze bardziej uwidaczniał się przy większych prędkościach obrotowych silnika. Było to spowodowane tym, że mniejsza energia zawarta $\mathrm{w}$ ubogiej mieszance wpływała na zwiększenie zwłoki zapłonu i spowalniało to rozprzestrzenianie się płomienia. Stwierdzono także, że najmniejszy czas spalania uzyskuje się dla mieszanek o współczynniku nadmiaru powietrza bliskim 1,0 dla wszystkich prędkości obrotowych [17]. Wzrost długości spalania powodował zmniejszenie maksymalnej temperatury oraz średniego ciśnienia efektywnego. Było to spowodowane wzrostem strat ciepła. Na podstawie wyników z pracy [17] stwierdzono także, że w celu uzyskania najlepszych osiągów silnika, mocy i zużycia paliwa, długość spalania powinna być w granicach 4-6 ms, to znaczy, że silnik powinien pracować na mieszance uboższej niż stechiometryczna $(\lambda=1,0-1,1)$. Bayraktar i Durgun [4] zaprezentowali korelację empiryczną dla określania długości spalania w silniku ZI. W tej korelacji ujęto wpływ parametrów pracy silnika na długość spalania. Długość spalania określono jako okres od wystąpienia zapłonu od iskry świecy zapłonowej do czasu całkowitego wypalenia dawki paliwa. $\mathrm{Na}$ podstawie wyników modelowania stwierdzono, że wzrost stopnia sprężania z 7 do 8,5 spowodowało skrócenie długości spalania. Dalsze zwiększanie stopnia sprężania nie spowodowało skrócenia długości spalania (parametry silnika: $\mathrm{n}=1000 \mathrm{obr} / \mathrm{min}$, zapłon $30^{\circ}$ przed GMP, $\lambda=1,0)$. Potwierdzono także, że kąt zapłonu wpływa na długość spalania.

$\mathrm{Na}$ podstawie analizy wybranych prac badawczych można stwierdzić, że długość spalania mieszanki w silniku ma istotne znaczenie dla uzyskiwanych parametrów pracy silnika oraz dla toksyczności spalin. W pracy przedstawiono wyniki modelowania wpływu EGR na opóźnienie zapłonu oraz na długość spalania w silniku z zapłonem iskrowym.

\section{Wyniki modelowania}

Modelowanie obiegu cieplnego silnika ZI przeprowadzono w programie FIRE [3]. Jako obiekt badań wykorzystano badawczy tłokowy, wolnossący silnik spalinowy o zapłonie iskrowym S320ER. Silnik pracował ze stałą prędkością obrotową $1000 \mathrm{obr} / \mathrm{min}$. Badania były prowadzone dla szerokiego zakresu współczynnika nadmiaru powietrza i udziału EGR, akceptowanego przez silnik. W czasie badań modelowych użyto zimny EGR. Podczas badań eksperymentalnych okazało się, że silnik charakteryzuje się dużą skłonnością do spalania stukowego. Podczas badań optymalizacyjnych brano pod uwagę ograniczający wpływ spalania stukowego [11, 14-16]. Jako paliwo przyjęto węglowodór $\mathrm{C}_{8} \mathrm{H}_{17}$ (ben- 
of the total inlet mass flow rate. The mean indicated pressure was determined for the angular range from $-180 \mathrm{deg}$ BTDC to $180 \mathrm{deg}$ ATDC. Determined an engine efficiency is the gross efficiency, the modelling does not include charge exchange loop. The ignition delay is defined as the time interval between the start of ignition and start of combustion. Start of the combustion is defined as the time at which the heat release rate reaches $1 \mathrm{~J} / \mathrm{deg}$ [9]. The end of the combustion process assumed the moment at which the heat release rate decreased by $90 \%$ after reaching its maximum [2].

Computational domain and results of experimental verification of model are presented in the already published or accepted for printing articles [14-16]. Modelling was carried out using the exhaust gas recirculation. For each share of EGR from 0 to $12.5 \%$ at $2.5 \%$ was also carried out optimization of ignition timing advance.

Effects of the use of exhaust gas recirculation is preferably on the content of $\mathrm{NO}_{\mathrm{x}}$ in the exhaust but also adversely affects of the thermodynamic parameters of thermal cycle engine. Optimizing the engine cycle in terms of the angle a)

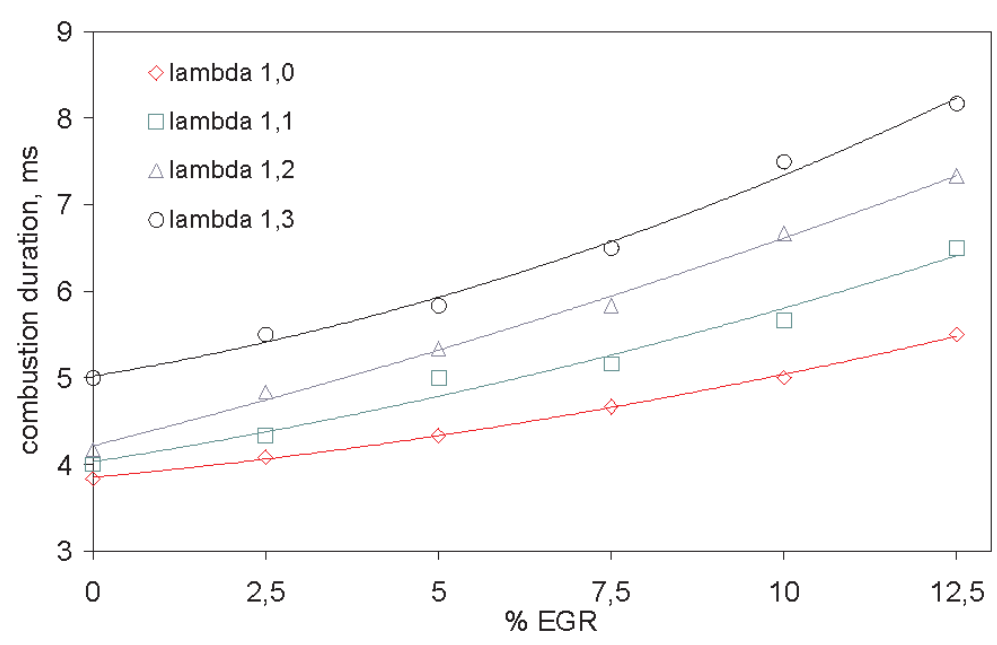

b)

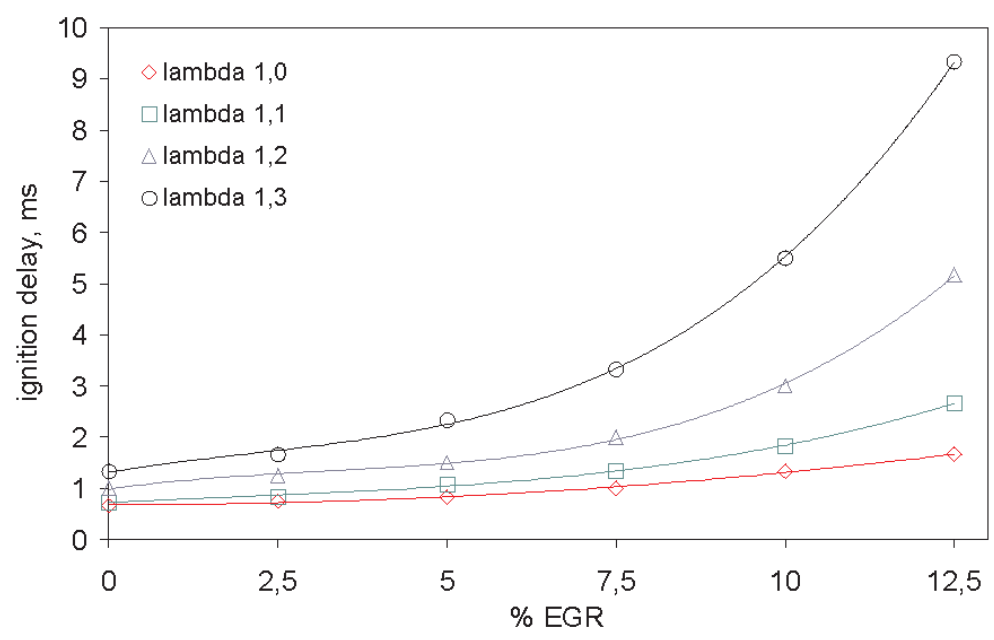

Fig. 1. Combustion duration (a) and ignition delay (b)

Rys. 1. Dlugość spalania (a) i opóźnienie zapłonu (b) zyna). Modelowanie procesu spalania przeprowadzono z wykorzystaniem modelu Extended Coherent Flame Model (ECFM) [3]. Wykorzystano model turbulencji k-zeta-f. Do cylindra doprowadzona była mieszanka homogeniczna. Udział procentowy recyrkulowanych spalin do układu dolotowego silnika (\% EGR) był określany jako procent całkowitej masy dostarczanej do cylindra. Średnie ciśnienie indykowane zostało określone dla zakresu kątowego od $-180^{\circ}$ przed GMP do $180^{\circ}$ po GMP. Wyznaczoną sprawność silnika należy traktować jako wartość brutto, ponieważ nie uwzględniono pętli wymiany ładunku. Okres opóźnienia zapłonu został zdefiniowany jako czas od momentu zapłonu do zapoczątkowania procesu spalania. Początek spalania został określony jako moment, w którym szybkość wydzielania ciepła osiągnęła wartość $1 \mathrm{~J} /{ }^{\circ}$ OWK [9]. Za koniec procesu spalania przyjęto moment, w którym szybkość wydzielania ciepła spadła o 90\% po osiągnięciu swojego maksimum [2]. Siatka obliczeniowa komory spalania oraz wyniki weryfikacji modelu zostały zaprezentowane w już opublikowanych i przyjętych do druku pracach [14-16]. W modelowaniu uwzględniono recyrkulację spalin. Dla wszystkich udziałów EGR od 0 do $12,5 \%$ co $2,5 \%$ przeprowadzono optymalizację kąta zapłonu.

Stosowanie recyrkulacji spalin korzystnie wpływa na zawartość NO w spalinach, ale jednocześnie niekorzystnie wpływa na parametry termodynamiczne obiegu cieplnego silnika. Optymalizując obieg silnika pod względem kąta zapłonu, uzyskuje się satysfakcjonujące parametry termodynamiczne silnika przy relatywnie niskiej emisji NO w spalinach. Ograniczeniem udziału EGR jest pogorszenie się warunków propagacji płomienia powiązane $\mathrm{z}$ mniejszą koncentracją tlenu w komorze spalania silnika. Wzrost zawartości recyrkulowanych spalin rozcieńcza mieszankę paliwowo-powietrzną, zmniejszając koncentrację tlenu, a w konsekwencji zmniejsza znacznie szybkość spalania.

Na rysunku 1 przedstawiono przebiegi wyznaczonej długości spalania i opóźnienia zapłonu w silniku badawczym przy różnych udziałach EGR. Na podstawie wyników można stwierdzić, że wzrost udziału EGR w silniku ZI powoduje wzrost długości spalania. Bez udziału EGR wzrost współczynnika nadmiaru powietrza $\mathrm{z} 1,0$ do 1,3 spowodowało wzrost długości spalania z 3,8 ms do 5,5 ms, czyli długość spalania wzrosła o prawie 45\%. Dla 12,5-procentowego udziału EGR parametr ten wzrósł z $5 \mathrm{~ms}$ do $8,3 \mathrm{~ms}$, czyli długość spalania wzrosła o prawie $65 \%$. Recyrkulacja spalin spowodowała także wzrost opóźnienia zapłonu. W sytuacji bez udziału recyrkulacji wzrost współczynnika nadmiaru powietrza z 1,0 do 1,3 spowodował wzrost opóźnienia zapłonu o 100\%, z 0,66 ms do 
of ignition is achieved satisfactory thermodynamic parameters of the engine at relatively low values of $\mathrm{NO}_{x}$ in the exhaust. The limit to the volume of EGR is the worsened flame propagation associated with reduced oxygen concentration in the combustion chamber. The increase of the percentage of EGR dilution in the air-fuel mixture decreases the oxygen concentration, and consequently, it decreases the combustion rate significantly.

Figure 1 shows the calculated the combustion duration and ignition delay for the test engine at different EGR share. On the basis of results can be seen that with increasing participation of EGR increases the combustion duration in the SI test engine. Without the participation of EGR increase in exces air ratio of 1.0 to 1.3 caused an increase in the combustion duration of $3.8 \mathrm{~ms}$ to $5.5 \mathrm{~ms}$, the combustion duration increased nearly by $45 \%$. For a $12.5 \%$ share of EGR, this increase was respectively from $5 \mathrm{~ms}$ to $8.3 \mathrm{~ms}$, the combustion duration increased nearly by $65 \%$.

Exhaust gas recirculation are also affected on the so-called ignition delay. In the case of a without EGR, increase of exces air ratio from 1.0 to 1.3 caused an increase in ignition delay by $100 \%$, from $0.66 \mathrm{~ms}$ to $1.3 \mathrm{~ms}$. Contrast with $12.4 \%$ EGR ignition delay increased from $1.3 \mathrm{~ms}$ to $9.3 \mathrm{~ms}$, which increased more than 7 times.

In Figure 2 are presented investigations of influence of excess air ratio on the combustion duration and ignition delay period for the engine with exhaust gas recirculation.

With the increase of excess air ratio, the modelled engine for various shares of the EGR, there was a rise in both the combustion duration and ignition delay period (Fig. 2). With the increase of excess air ratio while increasing the EGR participation, respectively these periods become longer.

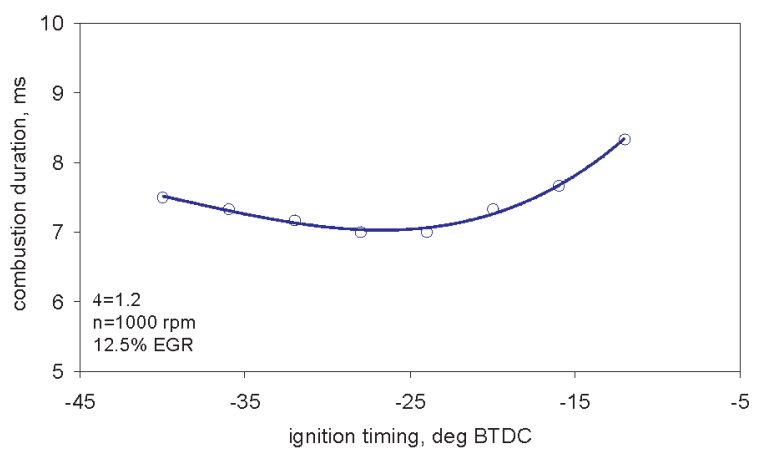

Fig. 3. Impact of timing advance for the combustion duration Rys. 3. Wplyw kąta zapłonu na długość spalania

b)
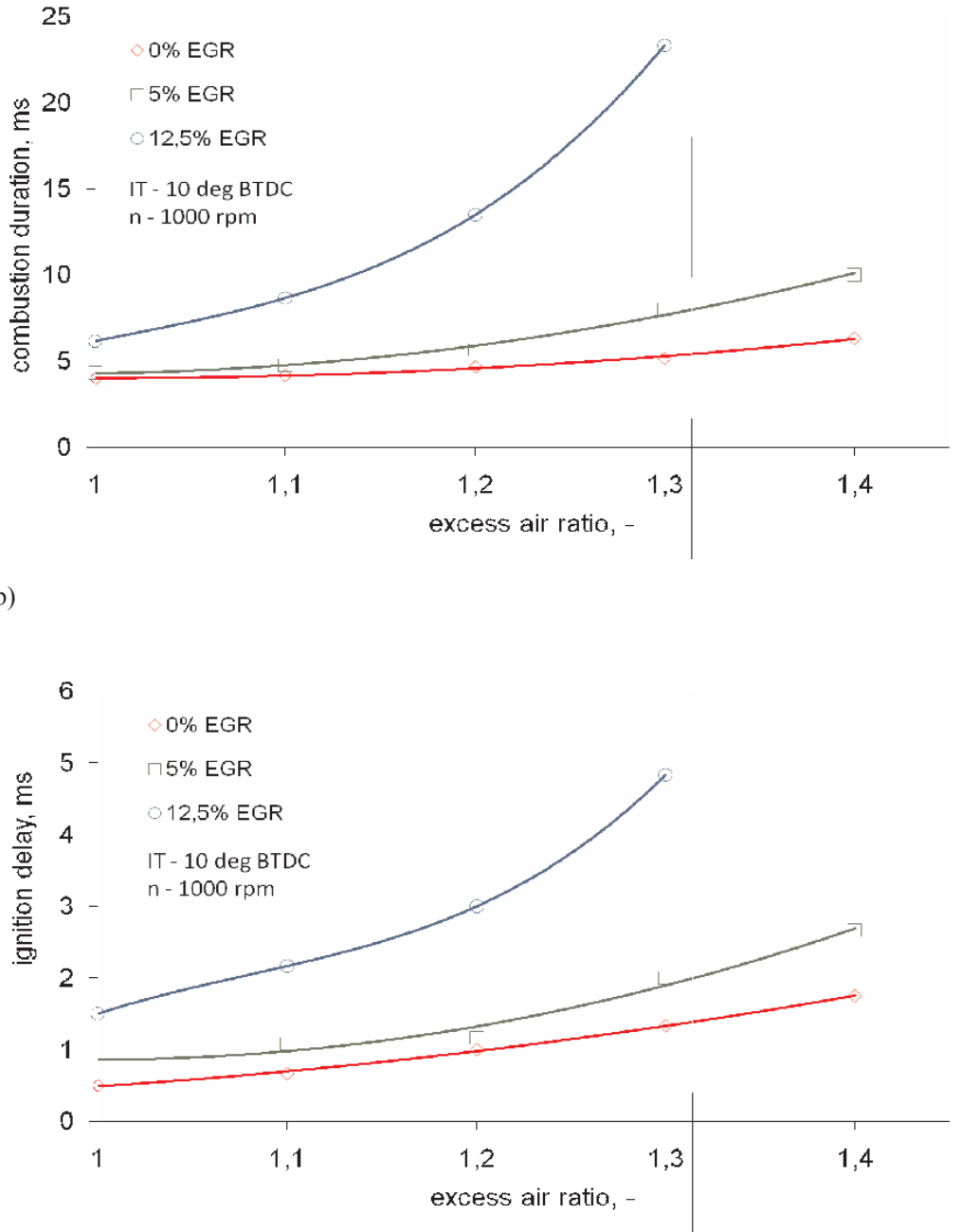

Fig. 2. Influence of excess air ratio on the combustion duration (a) and ignition delay period (b) for the engine with exhaust gas recirculation

Rys. 2. Wpływ współczynnika nadmiaru powietrza na długość spalania (a) i opóźnienie zapłonu (b) dla silnika z recyrkulacją spalin

1,3 ms. Przy 12,5-procentowym udziale EGR opóźnienie zapłonu wzrosło z 1,3 ms do 9,3 ms, czyli wzrosło ponad 7-krotnie.

Na rysunku 2 przedstawiono wyniki badania wpływu współczynnika nadmiaru powietrza na długość spalania i opóźnienie zapłonu dla silnika z recyrkulacją spalin.

Wraz ze wzrostem współczynnika nadmiaru powietrza, dla modelowanego silnika $\mathrm{z}$ różnymi udziałami EGR, nastąpił wzrost zarówno długości spalania, jak i opóźnienia zapłonu (rys. 2). Ze wzrostem współczynnika nadmiaru powietrza i jednocześnie wzrostem udziału EGR okresy te uległy wydłużeniu.

Teoretycznie [17] szybkość spalania powinna być taka, żeby długość spalania była minimalna przy dużym przyroście ciśnienia. Ciśnienie powinno osiągać maksimum w GMP, aby jak najmocniej oddziaływać w czasie suwu ekspansji. W praktyce silniki są tak konstruowane, aby tylko 50\% przyrostu ciśnienia występowało przed GMP, co powoduje, że wartość maksymalna ciśnienia i temperatury jest osiągana 


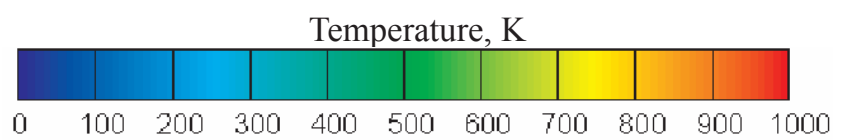

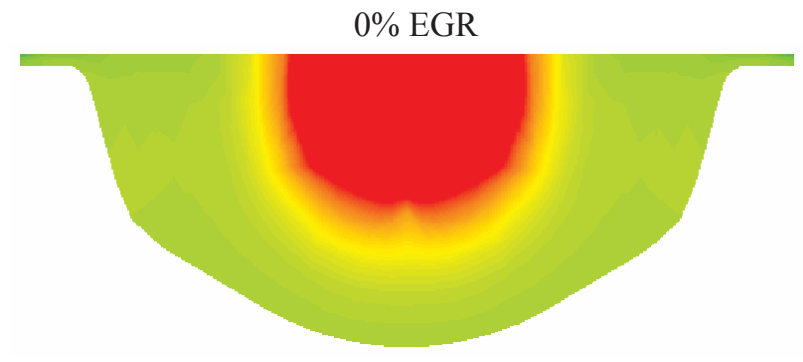

$5 \%$ EGR

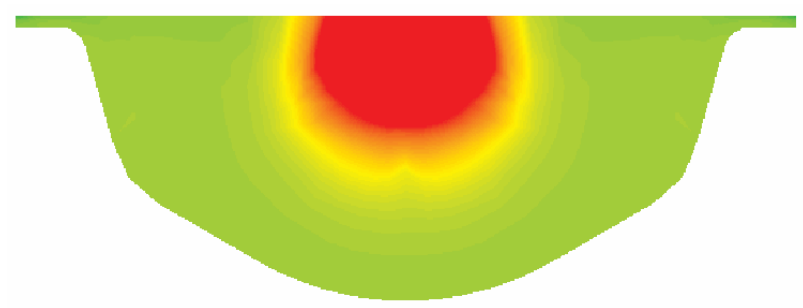

$10 \%$ EGR

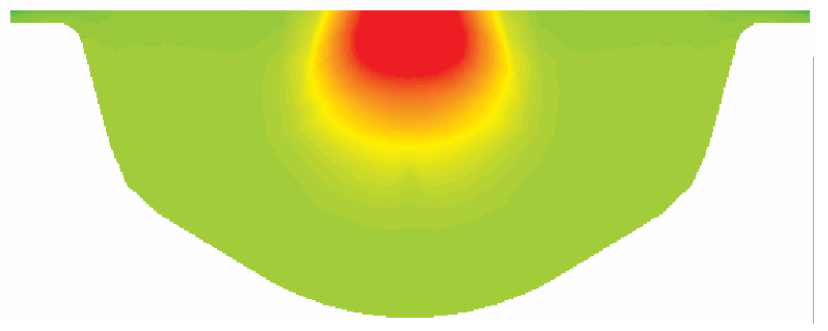

$12.5 \%$ EGR

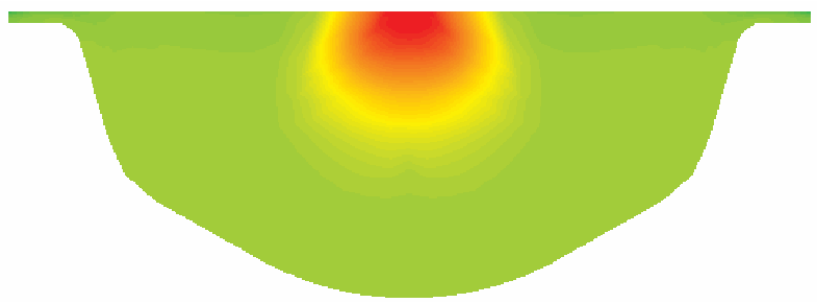

Fig. 4. Flame propagation in the combustion chamber of test engine at a range of EGR share, for $\lambda=1.2$, the position of the piston - TDC Rys. 4. Rozprzestrzenianie się plomienia w komorze spalania silnika badawczego z EGR, przy $\lambda=1,2$, położenie tłoka $w$ GMP

Theoretically [17], the rate of combustion should be such that combustion duration is minimum with the high rate of pressure rise. Pressure should be maximum just at TDC to produce greater force acting through a long period of the power stroke. In practice, engines are so designed that only $50 \%$ of the pressure rise is completed by the TDC, resulting in peak pressure and temperature occurring at 10-15 deg after TDC which reduces the heat loss and make the engine operation smooth [17].

Figure 3 shows the effect of timing advance for the combustion duration. In the test engine combustion process occurred fastest for timing advance equal to $28 \mathrm{deg}$ BTDC $(\lambda=1.2, \mathrm{n}=1000 \mathrm{rpm}, 12.5 \% \mathrm{EGR})$ and was about $7 \mathrm{~ms}$. The advancing and delaying the ignition angle caused an increase combustion delay.

Figure 4 shows the cross section of the combustion chamber, which shows the spreading flame front, the piston at TDC, with different shares of EGR. With the increasing share of the recirculated exhaust gases, the flame front spreads with less and less speed. This is probably caused by the ignition delay. Slower flame propagation increases the combustion duration.

\section{Summary}

The paper presents the impact of exhaust gas recirculation on ignition delay and combustion duration of the thermal cycle of internal combustion spark ignition engine. The optimization of thermal cycle was carried out in terms of ignition advance angle in order to obtain the possible highest efficiency. The results indicated a significant impact of EGR on the combustion duration. For a $12.5 \%$ share of the przy $10-15^{\circ}$ OWK po GMP, a to redukuje straty ciepła $\mathrm{i}$ sprawia, że silnik pracuje miękko [17].

Rysunek 3 przedstawia wpływ kąta wyprzedzenia zapłonu na długość spalania. W silniku badawczym proces spalania zachodził najszybciej dla kąta zapłonu równego $28^{\circ}$ po $\operatorname{GMP}(\lambda=1,2, \mathrm{n}=1000 \mathrm{obr} / \mathrm{min}, 12,5 \%$ EGR $)$ i wynosił $7 \mathrm{~ms}$. Wzrost kąta wyprzedzenia zapłonu powodował wzrost długości spalania.

Rysunek 4 przedstawia przekroje komory spalania, na których uwidoczniono rozprzestrzenianie się frontu płomienia, dla położenia tłoka w GMP, przy różnych udziałach EGR. Ze wzrostem udziału recyrkulowanych spalin front płomienia rozprzestrzenia się z coraz wolniej. Jest to prawdopodobnie spowodowane zwłoką zapłonu. Wolniejsze rozprzestrzenianie się płomienia powoduje wzrost długości spalania.

\section{Podsumowanie}

W artykule przedstawiono wpływ recyrkulacji spalin na opóźnienie zapłonu oraz długość spalania w obiegu cieplnym tłokowego silnika spalinowego. Przeprowadzono optymalizację obiegu silnika pod względem kąta wyprzedzenia zapłonu w celu uzyskania możliwie największej sprawności.

Wyniki badań wykazały wpływ EGR na długość spalania. Dla $\lambda=1,2$ i 12,5\% EGR, w zoptymalizowanych warunkach, długość spalania wzrosła o prawie $65 \% \mathrm{w}$ stosunku do pracy bez EGR. Przedstawiono także wpływ EGR na tzw. zwłokę zapłonu. Uwidoczniono silny wpływ recyrkulacji spalin na ten parametr. Dla rozpatrywanych warunków ( $\lambda=1,2$ i 12,5\% EGR) uzyskano 7-krotny 
EGR and $\lambda=1.2$, in optimized conditions, the combustion duration increased nearly by $65 \%$ in relation to the operation without EGR. It also describes the impact of EGR on the socalled ignition delay. Shown to strongly impact the exhaust gas recirculation on this parameter. For these conditions, the increase in ignition delay was 7 times bigger in comparison to conditions without EGR. With $12.5 \%$ share of the EGR was obtained 2.5 times of increase in rate of heat release. The best compromise between the indicated thermal efficiency and exhaust emission is reached at optimal ignition timing.

An increase in the combustion duration causes the peak temperature and mean indicated pressure to decrease. On the basis of results, it may be seen that NO emission is lower when combustion duration is high. This is because the peak temperature is low and therefore the formation of $\mathrm{NO}$ is reduces.

Exhaust gas recirculation is beneficial not only to reduce the toxicity of exhaust gases but it also strongly influences of the ignition delay and combustion duration of the engine. wzrost opóźnienia zapłonu w porównaniu do warunków bez EGR. Przy 12,5-procentowym udziale EGR uzyskano także 2,5-krotny wzrost szybkości wydzielania ciepła. Najlepszy kompromis pomiędzy wartością sprawności indykowanej a emisją spalin uzyskano dla optymalnego kąta zapłonu.

Wzrost długości spalania powoduje zmniejszenie wartości maksymalnej temperatury i średniego ciśnienia indykowanego. Na podstawie wyników można stwierdzić, że emisja NO jest niższa, gdy długość spalania jest większa. Jest to spowodowane właśnie zmniejszeniem wartości maksymalnej temperatury, a przez to ograniczenie tworzenia się NO. Recyrkulacja spalin nie tylko korzystnie wpływa na toksyczność spalin, ale także silnie wpływa na wartości opóźnienia zapłonu oraz na długość spalania w silniku tłokowym.

Paper reviewed/Artykut recenzowany

\section{Bibliography/Literatura}

[1] Abd-Alla G.H.: Using exhaust gas recirculation in internal combustion engines: a review. Energy Conversion and Management 43, 2002.

[2] Amr I., Saiful B.: Optimization of a natural gas SI engine employing EGR strategy using a two-zone combustion model, Fuel 87, 2008.

[3] AVL FIRE, VERSION 2009 ICE Physics \& Chemistry. Combustion, Emission, Spray, Wallfilm. Users Guide, 2009.

[4] Bayraktar H., Durgun O.: Development of an empirical correlation for combustion durations in spark ignition engines. Energy Conversion and Management 45, 2004.

[5] Cha J., Kwon J., Cho Y., Park S.: The Effect of Exhaust Gas Recirculation (EGR) on Combustion Stability, Engine Performance and Exhaust Emissions in a Gasoline Engine. KSME International Journal, Vol. 15, No. 10, 2001.

[6] Cupiał K., Tutak W., Jamrozik A., Kociszewski A.: The accuracy of modelling of the thermal cycle of a compression ignition engine. Combustion Engines, 2011.

[7] Heywood J. B.: Internal Combustion Engine Fundamentals. New York: McGraw-Hill, 1988.

[8] Jamrozik A., Tutak W.: Modelling of combustion process in the gas test engine. Perspective Technologies and Methods in Mems Design, MEMSTECH, Lviv - Polyana, Ukraine 2010.

Wojciech Tutak, DEng. - doctor in the Faculty of Mechanical Engineering and Computer Science of Częstochowa University of Technology.

Dr inż. Wojciech Tutak - adiunkt na Wydziale Inżynierii Mechanicznej i Informatyki Politechniki Częstochowskiej.

e-mail: tutak@imtits.pcz.czest.pl

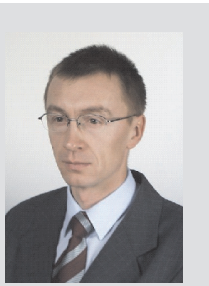

[9] Li J., Gong H.M., Su Y., Dou H.L., Liu X.J.: Effect of injection and ignition timings on performance and emissions from a spark-ignition engine fueled with methanol. Fuel 89, 2010.

[10] Szwaja S.: Combustion Knock - Heat Release Rate Correlation of a Hydrogen Fueled IC Engine Work Cycles, 9th International Conference on Heat Engines and Environmental Protection. Proceedings. Balatonfured, s. 3-88, Hangary 2009.

[11] Tutak W., Jamrozik A.: Modeling of thermal cycle of gas engine using AVL FIRE software. Silniki Spalinowe 2010.

[12] Tutak W., Jamrozik A., Kociszewski A.: Improved Emission Characteristics of SI Test Engine by EGR, Proceedings of VIIthInternational Conference in MEMS Design, MEMSTECH'2011, Lviv-Polyana 2011.

[13] Tutak W., Jamrozik A., Kociszewski A., Sosnowski M.: Numerical analysis of initial swirl profile influence on modelled piston engine work cycle parameters. Combustion Engines, 2007-SC2, 2007.

[14] Tutak W., Jamrozik A., Kociszewski A.: Three Dimensional Modelling of Combustion Process in SI Engine with Exhaust Gas Recirculation . Proceedings of 10thInternational Conference on Heat Engines and Environmental Protection, Balatonfüred, Hungary 2011.

[15] Tutak W.: Numerical analysis of some parameters of SI internal combustion engine with exhaust gas recirculation. TEKA PAN, Lublin 2011.

[16] Tutak W.: Numerical analysis of the impact of EGR on the knock limit in SI test engine. TEKA PAN, Lublin 2011.

[17] Yamin J.A.A., Gupta H.N., Bansal B.B., Srivastava O.N.: Effect of combustion duration on the performance and emission characteristics of a spark ignition engine using hydrogen as a fuel. International Journal of Hydrogen Energy 25, 2000.

[18] Zou H., Wang L., Liu S., Li Y.: Ignition delay of dual fuel engine operating with methanol ignited by pilot diesel. Frontiers of Energy and Power Engineering in China 2008. 